IZA DP No. 7369

Families, Taxes and the Welfare System

Nicole B. Simpson

April 2013 


\title{
Families, Taxes and the Welfare System
}

\author{
Nicole B. Simpson \\ Colgate University \\ and IZA
}
Discussion Paper No. 7369
April 2013

\author{
IZA \\ P.O. Box 7240 \\ 53072 Bonn \\ Germany \\ Phone: +49-228-3894-0 \\ Fax: +49-228-3894-180 \\ E-mail: iza@iza.org
}

Any opinions expressed here are those of the author(s) and not those of IZA. Research published in this series may include views on policy, but the institute itself takes no institutional policy positions. The IZA research network is committed to the IZA Guiding Principles of Research Integrity.

The Institute for the Study of Labor (IZA) in Bonn is a local and virtual international research center and a place of communication between science, politics and business. IZA is an independent nonprofit organization supported by Deutsche Post Foundation. The center is associated with the University of Bonn and offers a stimulating research environment through its international network, workshops and conferences, data service, project support, research visits and doctoral program. IZA engages in (i) original and internationally competitive research in all fields of labor economics, (ii) development of policy concepts, and (iii) dissemination of research results and concepts to the interested public.

IZA Discussion Papers often represent preliminary work and are circulated to encourage discussion. Citation of such a paper should account for its provisional character. A revised version may be available directly from the author. 
IZA Discussion Paper No. 7369

April 2013

\section{ABSTRACT}

\section{Families, Taxes and the Welfare System}

In this paper, I will describe in detail both the Earned Income Tax Credit and the Child Tax Credit in the U.S., including their origins, their structure, and the effects they have on the labor market and family formation. I will then discuss the macroeconomic implications of U.S. welfare reform, and then conclude by analyzing the effectiveness of the U.S. safety net (broadly defined) during the Great Recession of 2007-2008.

JEL Classification: D1, H24, H53

Keywords: $\quad$ taxes, welfare, families, EITC, child tax credit, TANF

Corresponding author:

Nicole B. Simpson

Colgate University

Department of Economics

13 Oak Dr.

Hamilton, NY 13346

USA

E-mail: nsimpson@colgate.edu 


\section{Introduction}

Fiscal policy in the U.S. has evolved over the last fifty years. Income tax rates have fallen across all levels of income, with the largest reductions occurring for households at the top of the income distribution. Thus, income taxes are much less progressive in the United States than they used to be. The reduction in income taxes comes at a cost: with fewer tax revenues, it makes it more difficult for the U.S. government to justify increases in many of its programs, and especially those targeting low-income families. This, in part, motivated the welfare-to-work

programs in the 1990s that fundamentally changed the notion of traditional welfare in the U.S. It was at this moment that other significant changes occurred for families in regards to U.S. tax policies: traditional welfare was made less generous through the imposition of strict lifetime limits, the Federal government expanded the Earned Income Tax Credit (EITC) and introduced the Child Tax Credit (CTC). Today, the EITC and CTC form the pillars of anti-poverty programs for families in the United States. In this chapter, I will describe in detail both the EITC and CTC, including their origins, their structure, and the effects they have on the labor market and family formation. I will then discuss the macroeconomic implications of U.S. welfare reform, and then conclude by analyzing the effectiveness of the U.S. safety net (broadly defined) during the Great Recession of 2007-2008.

In my analysis, I start by detailing the current U.S. income tax system as it pertains to families. The evolution of the U.S. tax code has led to a complex system of credits and deductions that have important effects on families. As with most government programs, the tax credits that families face are income-contingent and phase out as incomes increase. The phasing out of tax credits typically involves a reduction in the tax credit at a constant rate as incomes rise until a point in which the credit disappears. The "phase-out” rate (as often labeled) is an 
effective marginal tax rate. Thus, households with income in the phase-out range (which represent the vast majority of recipients) often experience some of the highest marginal income tax rate in the U.S. For example, a family of four (two adults and two children) earning $\$ 30,000$ in 2012 experiences a reduction in their EITC of 21\% for every additional dollar they earn. In addition, this family falls in the Federal income tax bracket of $10 \%$. Thus, the effective marginal tax rate for them is $31 \%$. This is higher than the tax rate faced by similar families making $\$ 150,000$ in $2012 .{ }^{1}$ The $31 \%$ income tax rate does not even include the phasing out of other tax credits (such as the CTC). Thus, the complex array of tax credits for low- and middle-income families is hitting them with some of the highest marginal income tax rates in the U.S. today. In my discussion below, I will summarize the literature that documents the important distortionary effects these high marginal tax rates have on labor market participation and family formation.

The overhaul of traditional welfare in the mid 1990's which consisted of replacing Aid to Families with Dependent Children (AFDC) with Temporary Aid to Needy Families (TANF) led to important macroeconomic effects; most relevant is that total spending on welfare grew at modest rates while spending on tax credits increased dramatically. Figure 1 clearly documents the key trends on real Federal spending on AFDC/TANF, the EITC and CTC since 1975. Prior to the early 1990's, spending on AFDC far surpassed Federal spending on the EITC (in 2009 dollars). However, in 1993, real spending on the EITC was for the first time larger than spending on AFDC, and since then, has experienced significant increases over time. This compares to the relatively stagnant growth in TANF in recent years. In addition, the CTC was first introduced in 1997, and similar to the EITC, has expanded in both size and scope over time. In fact, since 2004, total Federal spending on the CTC has exceeded spending on TANF. The shift in the last two decades, from a safety net that consists primarily of welfare to one that

\footnotetext{
${ }^{1}$ http://www.taxpolicycenter.org/taxfacts/Content/PDF/individual_rates.pdf
} 
consists largely of tax credits, represents a significant change in both the process and the frequency through which these funds are distributed to households. Since tax credits are issued during the income tax preparation process, their allocation is lumpy as they are distributed on an annual basis. This has important macroeconomic effects on the U.S. economy, which will be discussed below.

Figure 1. Federal Spending on the EITC, CTC and AFDC

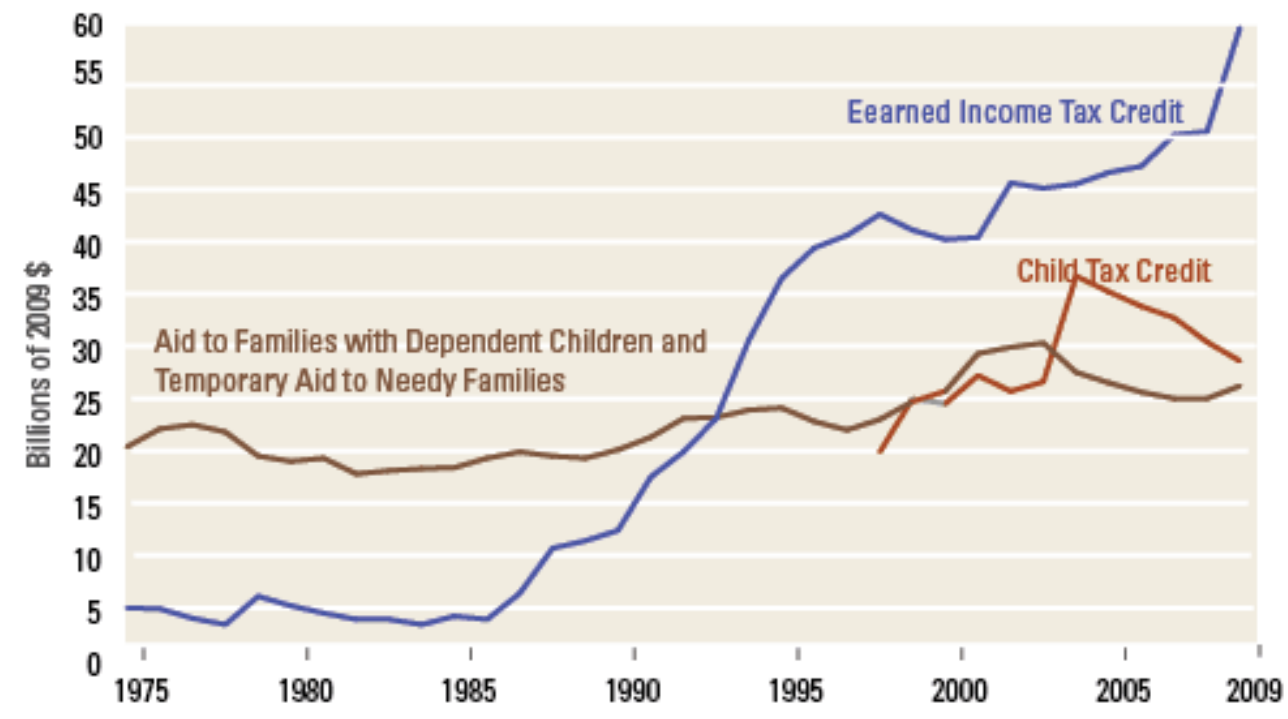

Source: http://www.taxpolicycenter.org/briefing-book/key-elements/family/eitc.cfm

Certainly, the U.S. safety net for families consists of other components, including unemployment insurance, food stamps and Medicaid, to name a few. While I will not devote time in this chapter to discuss all of the components of the existing safety net for families in the U.S., I will offer some broad remarks on how the system as a whole reacts during macroeconomic contractions. As I will document below, many government programs are counter-cyclical, such that in times of recession, spending on these programs increase. In fact, during the Great Recession of 2007-08, participation rates in the food stamp program, the Supplemental Nutrition Assistance Program (SNAP), have sky-rocketed, leading to significant 
increases in its spending; in fact, SNAP just surpassed the EITC as the largest anti-poverty program in the U.S. by spending $\$ 77$ billion in 2011 (Austin and Levit, 2012). In addition, spending on unemployment insurance reached \$120 billion in 2009 (Austin and Levit, 2010). However, spending and participation rates in TANF did not significantly increase during the recession, begging the question about whether or not TANF is truly serving as a reliable safety net when families need it the most.

While a significant amount of research exists that analyzes the effects of U.S. tax and transfer policy on families (some of which I will document), there remains several questions that remain unanswered. I will conclude my chapter by discussing a few topics that should be explored in the future so that we better understand how the system of tax credits and government programs are used by families in the U.S. and their impacts on important economic decisions.

\section{U.S. Income Taxes and the Child Tax Credit}

The U.S. Federal income tax code is one of the most complex income tax systems in the world. The average American has very little understanding about the overall structure of income tax rates and tax credits. As a result, the distortionary effects of income taxes and tax credits are unclear. In this section, I will summarize the trends in the U.S. income tax system, with an emphasis on how marginal tax rates have decreased over time across all income levels. Simple economic theory show us that lower marginal income taxes rates have an ambiguous effect on labor supply, and I will document existing empirical literature on both the labor market and family formation effects. In addition, I will discuss the origins and structure of the Child Tax Credit and summarize recent findings on its effects for U.S. families. 
The U.S. income tax code is a bracket system, where household income is taxed at different rates for different levels of income. ${ }^{2}$ Figure 2 displays the brackets and corresponding tax rate for tax year 2012 based on filing statuses 'head of household' and 'married filing jointly' (note that single parents file as head of household so that is the relevant group when focusing on families). First note that the lowest tax rate is $10 \%$ and the highest rate is $35 \%$, and both of these rates were set as of the Economic Growth and Tax Relief Reconciliation Act of 2001 (EGTRRA). The table does not include standard deductions, which were $\$ 8,700$ for head of households and \$11,900 for married filing jointly in 2012. ${ }^{3}$ Notice that income ranges for married households are larger, and are more generous for higher income levels. For example, in the lowest tax bracket, married households can earn approximately $\$ 5,000$ more than head of households (with one earner) and still face the same tax rate. However, for taxpayers in the middle income tax brackets (15-28\% rates), the difference is approximately $\$ 20,000$ more. The difference disappears at the highest tax rates. This increase in the income range for income taxes started with EGTRRA 2001, which aimed to reduce the tax penalty for marriage filers. Still, the U.S. income tax code continues to penalize marriage as the income ranges for households in the 15 percent tax rate and higher are not twice as large as those for single filers. ${ }^{4}$

The existence of a marriage penalty in the U.S. tax code would theoretically reduce the incentive to marry or to remain married, according to the standard Becker marriage model (Becker, 1991). The empirical literature on the topic is generally consistent with this view. For example, at the macro-level, the aggregate marriage rate in the United States has fallen as the average tax penalty has increased (Alm and Whittington, 1995). Similary, at the micro-level, the

\footnotetext{
${ }^{2}$ It is important to note that most U.S. states have their income tax bracket, but given the heterogeneity in these systems, I will focus on Federal rates.

${ }^{3} \mathrm{http}: / /$ www.taxpolicycenter.org/taxfacts/Content/PDF/individual_rates.pdf

${ }^{4}$ http://www.taxpolicycenter.org/taxtopics/Marriage-Penalties.cfm
} 
probability of marriage and the probability of divorce (especially for women) falls as the marriage penalty increases (Alm and Whittington, 1997 and 1999). Thus, the existence of marriage penalties in the U.S. tax code continues to reduce the incentive to get and stay married.

Figure 2. Federal U.S. Income Tax Rates, 2012

\begin{tabular}{|c|c|c|}
\hline \multicolumn{2}{|c|}{ Taxable Income } & \multirow[b]{3}{*}{ Marginal Rate } \\
\hline & But not & \\
\hline Dver -.. & over -.. & \\
\hline$\$ 0$ & $\$ 12,400$ & $10 \%$ \\
\hline$\$ 12,400$ & $\$ 47,350$ & $15 \%$ \\
\hline$\$ 47,350$ & $\$ 122,300$ & $25 \%$ \\
\hline$\$ 122,300$ & $\$ 198,050$ & $28 \%$ \\
\hline$\$ 198,050$ & $\$ 388,350$ & $33 \%$ \\
\hline$\$ 388,350$ & and over & $35 \%$ \\
\hline
\end{tabular}

\begin{tabular}{|c|c|c|}
\hline \multicolumn{2}{|c|}{ Taxable Inoome } & \multirow[b]{2}{*}{ Marginal Fate } \\
\hline Dhuer --. & $\begin{array}{c}\text { But not } \\
\text { outer -- }\end{array}$ & \\
\hline$\$ 0$ & 417.400 & $10 \%$ \\
\hline$\$ 17.400$ & $\$ 70,700$ & $15 \%$ \\
\hline$\$ 70,700$ & $\$ 142,700$ & 258 \\
\hline$\$ 142,700$ & $\$ 217.450$ & $28 \%$ \\
\hline$\$ 217,450$ & $\$ 389,350$ & 336 \\
\hline$\$ 398,350$ & and ouger & $35 \%$ \\
\hline
\end{tabular}

Source: http://www.taxpolicycenter.org/taxfacts/Content/PDF/individual_rates.pdf

Since the early 1970s, the U.S. income tax system has become less progressive. Figure 3 plots the highest and the lowest Federal income tax rate since 1913. As evident, the bottom rate rate peaked at 23\% immediately following WWII and has generally fallen over time, with the exception of the period between 1987 and 2000 when the lowest income tax rate was 15\%. Overall, there has been little variability in the lowest income tax rate for the last several decades. This contrasts to the highest income tax rate which peaked at $92 \%$ in 1952-1953, fell to $70 \%$ in the 1970 s, and then went to $39.6 \%$ starting in the mid-1990s and is now at $35 \%$ in recent years. Thus, the highest income tax rate has been halved in the last four decades. Comparing the highest and lowest rate is only one way to measure the progressivity of an income tax system, but most other measures would tell the same story: income tax rates have fallen dramatically in the U.S. during the last several decades, with the largest reductions occurring for those with the highest incomes. 
Standard economic theory, using a static labor/leisure model, indicates that lower income tax rates will have ambiguous effects on labor supply. That is, an increase in after-tax wages as a result of a decrease in marginal tax rates will lead to an increase in labor supply if the substitution effect dominates, such that households will substitute away from leisure and towards labor. However, the income effect works in the opposite direction, such that a higher after-tax wage rate allows households to work less to achieve the desired level of savings. The net effect depends on which effect dominates, however, at the macroeconomic level, it is usually assumed that that substitution effect dominates, suggesting that households work more in response to a reduction in labor income tax rates. The vast empirical literature on the subject indicates that the effects of tax rate changes on the intensive margin of labor supply (the margin in which the household decides how much to work) are small, but that tax changes have large effects on the extensive margin of labor supply, namely, whether to work or not (i.e., labor market participation). And this is especially prevalent among programs such as the EITC that induce large negative marginal tax rates (Eissa and Liebman, 1996; Meyer and Rosenbaum, 2001; Blundell, 2001). In fact, Robins (1985) and others document that labor market participation rates respond more to changes in tax rates compared to the response of annual hours worked for both single female heads of households and married women. More recently, Eissa, Kleven and Kreiner (2008) document that the extensive margin effects are especially significant and important for single mothers. Thus, changes in income tax rates have important effects on labor market participation and in particular for single mothers and married women. 
Figure 3. Lowest and Highest Federal Income Tax Rates, 1913-2012

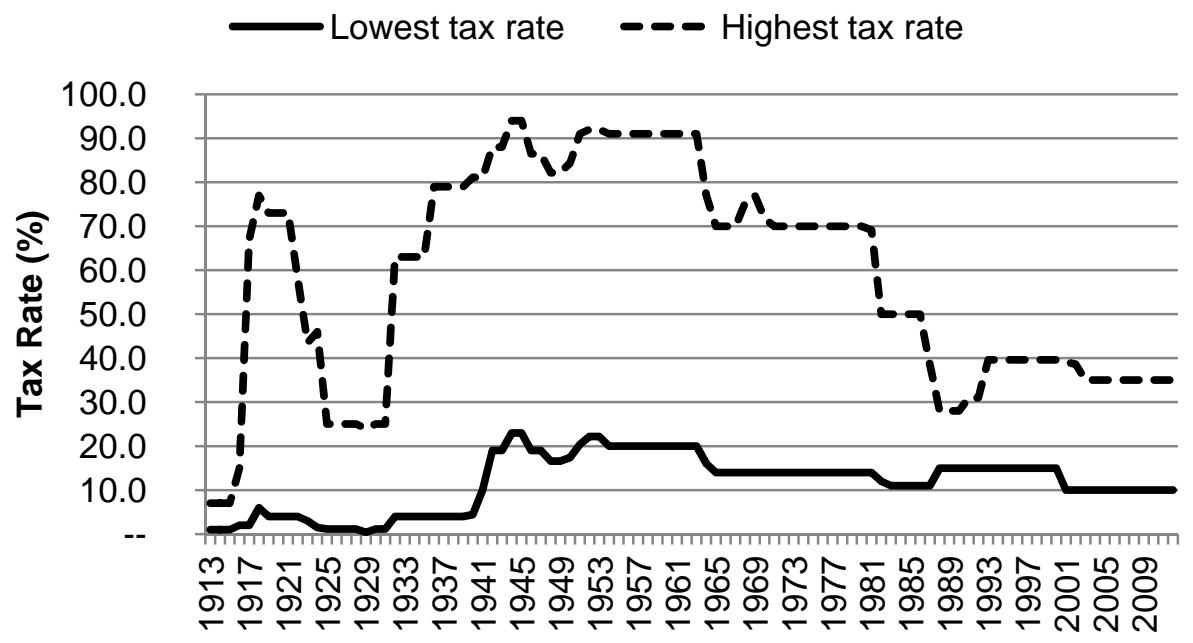

Tax Year

Source:http://www.taxpolicycenter.org/taxfacts/displayafact.cfm?DocID=543\&Topic2id=30\&Topic3id=39

The Child Tax Credit was originally enacted in 1997 as part of the Taxpayer Relief Act. Initially, the CTC represented a \$400 tax credit for dependent children under the age of 17, and eligibility phased out at high income levels (the tax credit was increased to $\$ 500$ in subsequent years). However, households with no tax liability did not qualify for the credit, so the majority of the credit was issued to middle-income households (Burman and Wheaton, 2005). Tax reform in 2001 increased the cap at a gradual rate from $\$ 600$ beginning in 2001 to $\$ 1,000$ in 2010. In the 2003 tax reform, the credit was set to $\$ 1,000$ and has remained there since. Importantly, tax reforms beginning in 2001 allowed most families to receive a credit in excess of their tax liability. The expanded refundable tax credit made the CTC more valuable to many lowerincome families (Burman and Wheaton, 2005), though many with very low incomes (below $\$ 10,000$ at the time) did not qualify for the credit. The refundable component of the CTC is called the Additional Child Tax Credit. In total, the CTC costs close to $\$ 60$ billion each year, of 
which approximately half is government outlays and the rest is reductions in government tax revenues (Congressional Budget Office (CBO), 2013). ${ }^{5}$

Figure 4 displays the structure of the Child Tax Credit for 2012. For relatively low levels of income, the CTC increases with earnings at a rate of $15 \%$; a $\$ 1,000$ increase in earnings would lead to an additional \$150 in CTC. The CTC increases at this constant rate until it hits a maximum of $\$ 1,000$ per child. Once taxable income is over the threshold, the total credit decreases by $\$ 50$ for each $\$ 1,000$ of income, implying a phase out rate of $5 \%$. The thresholds for phasing in and out of the CTC vary over time with inflation. However, beginning in 2009, households with $\$ 3,000$ or more of earned income qualify for the CTC (Sherman, 2009). In 2012 , for married filers earning $\$ 110,000$ and all others earning $\$ 75,000$, the credit begins to phase out (at the $5 \%$ rate). ${ }^{6}$

Figure 4. Child Tax Credit, Tax Year 2012

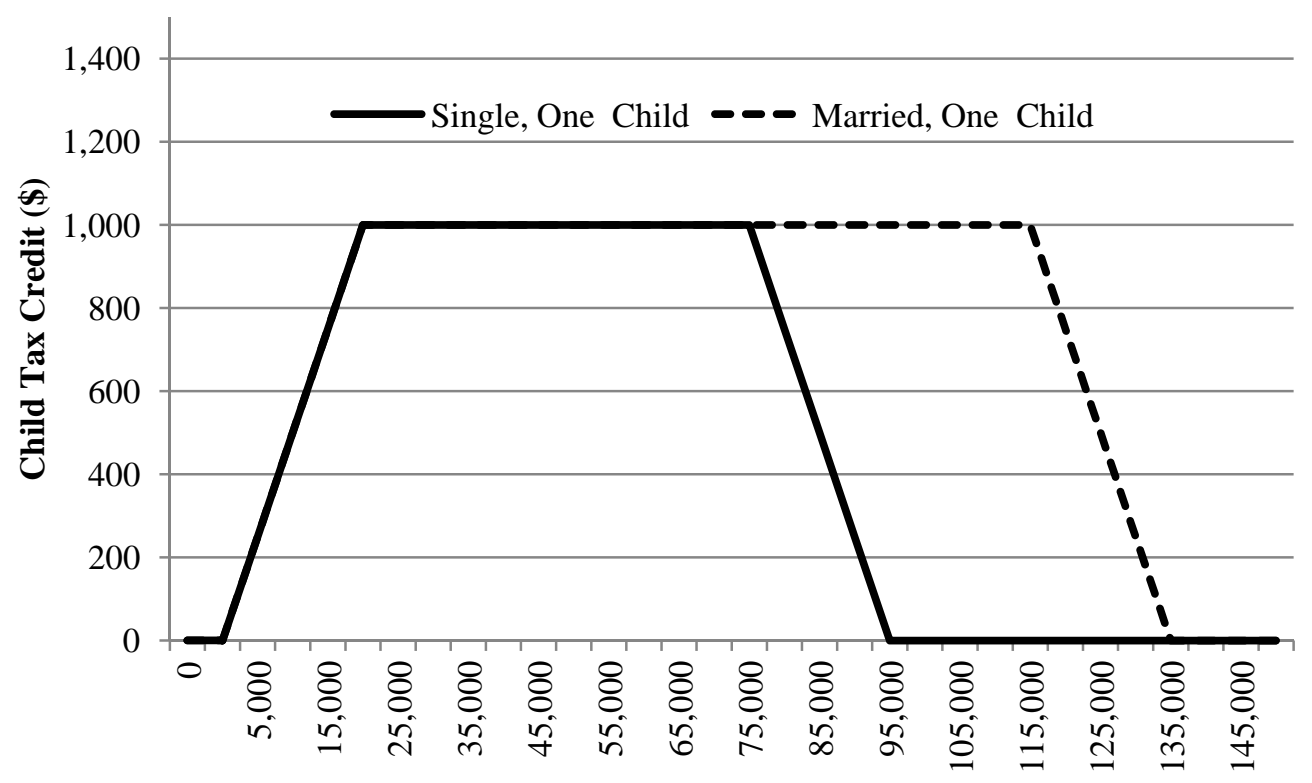

Adjusted Gross Income (\$)

Source: Author's calculations based on data from the IRS

\footnotetext{
${ }^{5}$ In the federal budget, the portion of refundable credits that is used to reduce the amount of taxes owed is counted as a reduction in revenues, and the portion that exceeds tax liabilities (the refundable portion) is treated as an outlay. ${ }^{6}$ http://www.cbpp.org/cms/index.cfm?fa=view\&id=2989
} 
Designed to phase in with earnings, this CTC provides a work incentive and offsets some of the disincentives created by the phasing-out of the earned income tax credit and the income tax itself, both of which affect moderately low-income families (the phasing out of the EITC occurs for much lower income levels, as discussed in the next section). The phasing in and out of the CTC changes the marginal income tax rates that households face. The phase-in will add 15 percentage points to the marginal income tax rate: for example, a single parent earning $\$ 15,000$ falls in the $10 \%$ income tax bracket (according to Figure 2) and a negative tax rate of 15\% due to the CTC (not including the EITC), so that the net marginal tax rate is $-5 \%$. Highincome single parents earning $\$ 85,000$ are in the $25 \%$ income tax bracket and are being phased out of the CTC at a rate of 5\%. Thus, their marginal income tax rate is effectively $30 \%$. Thus, the phasing in and out of the CTC, similar to the EITC and other government transfer programs, has important effects on the marginal income tax rate for households and hence labor supply distortions, as described above.

To date, there is very little work examining the effects of the child tax credit in the U.S., with the exception of recent work analyzing the consumption patterns of households. Johnson, Parker and Souleles (2009) use household-level data from the U.S. Consumer Expenditure Survey to measure consumers’ spending response to the 2003 advanced child tax credit rebate. They find that consumers spent approximately $25 \%$ of the rebates in the quarter they received their checks. However, a recent study by Michel and Ahmad (2012) suggests that these consumption effects are overstated. By studying the beginning of the CTC and the 2003 expansion, Michel and Ahmad (2012) find little evidence that the CTC increased consumption in the short-term. 
Researchers from other countries, namely Canada and the UK, where child tax credits have existed for a longer period of time, have provided several important findings. For example, the "child benefit" in the UK, which is similar to the CTC but is lump sum and dispersed weekly through paychecks, has existed for more than twenty years. In a recent paper, Blow, Walker and $\mathrm{Zu}$ (2012) find that the child benefit is spent differently from regular income; however, it is more often spent on goods for the adults than for the children. Their results are true for single parents as well as for couples.

There is some evidence that child tax credits affect fertility. Using Canadian data, Zhang, Quan, and Van Meerbergen (1994) find that the fertility effects of the child tax credit in Canada are significant and positive using a dataset that spans the period between 1977 (the inception of the child tax credit in Canada) and 1988. Relatedly, work by Whittington, Alm, and Peters (1990) finds that the personal tax exemption for dependents in the U.S. has a significant positive effect on fertility.

Since the CTC affects both low- and middle-income families, its effects on fertility, labor market participation and the macroeconomy need to be better understood. This contrasts to the burgeoning literature on the EITC, which is summarized in the next section.

\section{The EITC}

The EITC started as a modest program as part of the Tax Reduction Act of 1975. The program was unique among tax credits as it was refundable so that poor families could utilize its benefits even if they owed little or no taxes. The EITC has evolved over time. ${ }^{7}$ The Tax Reform Act of 1986 indexed the EITC to inflation and liberalized the EITC. The Omnibus Reconciliation Act

\footnotetext{
${ }^{7}$ For a more detailed history of the EITC, refer to Hotz and Scholz (2003).
} 
(OBRA) of 1990 increased the credit and added separate schedules for families with two or more children. The largest expansion of the EITC occurred in 1993, as part of the OBRA, in which the EITC was increased by an additional 25 percent. Families with two or more children experienced the largest increase in the credit, and childless filers could, for the first time, qualify for the EITC.

Until 2001, the structure of the EITC was identical for single and married filers. However, as part EGTRRA 2001, married couples received larger benefits for larger ranges of income levels than single filers. Finally, the American Recovery and Reinvestment Act of 2009 increased the credit for families with three or more children and expanded eligibility for married couples. Now, families making up to $\$ 50,270$ in annual earnings in 2012 could qualify for the tax credit, with the maximum credit of $\$ 5,891$ for a family with three or more children. The latest expansion of the EITC is expected to help an additional 650,000 households and 1.4 million children. ${ }^{8}$ The success of the federal EITC has led to the development of similar programs in 24 U.S. states and the District of Columbia.

The EITC acts as an after-tax wage subsidy for low-income workers and depends on earned income, number of children and marital status. ${ }^{9}$ Earned income includes: wages, salaries, tips and other employee compensation; union long-term disability benefits received prior to minimum retirement age; and net earnings from self-employment. However, it does not include social security benefits, unemployment compensation, welfare benefits, scholarships, worker's compensation benefits, or pension/annuity income.

The EITC is structured in three phases: in the phase-in period, the credit increases with earnings; in the plateau period, the credit reaches a maximum and levels off; and in the phase-

\footnotetext{
${ }^{8}$ Tax Policy Center (2009).

${ }^{9}$ Many of the poorest families are ineligible for the EITC since they their earnings are too low to qualify and/or they do not have children.
} 
out period, the credit falls as the claimant's earnings rise. At the eligibility limit, the household earns no EITC. The EITC is separated into different levels for claimants with no children, those with one child, and those with two or more children. There are also different tax credits for different types of filers; married couples filing jointly are eligible for slightly higher credit amounts in the phase-out period than single filers and have slightly larger income eligibility ranges. Figure 5 presents the details of the EITC for tax year 2012 for different filing statuses (single or married) and number of children, and includes the maximum credits and earnings limitations. The EITC parameters are displayed in Table 1.

Figure 5. EITC Structure, Tax Year 2012

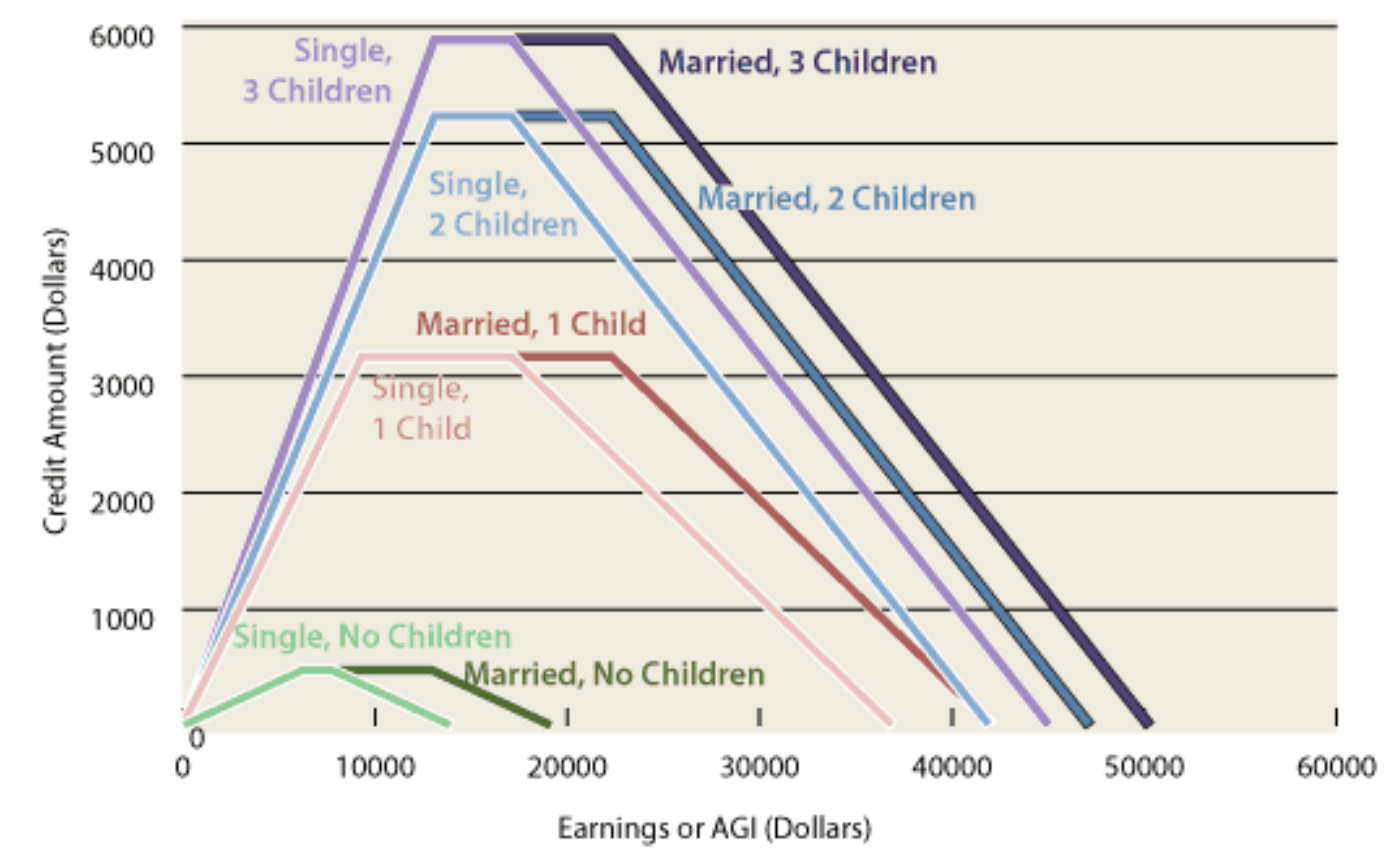

Source: http://www.taxpolicycenter.org/briefing-book/key-elements/family/eitc.cfm

As seen in Figure 5 and Table 1, the EITC significantly varies with the number of children present in a household. Childless filers receive less than one-seventh of the EITC than filers with one child and one-twelfth of filers with three or more children. The federal credit can represent between 34, 40, and 45 percent of income for filers with one, two, and three or more 
children, respectively. In addition to the Federal EITC, many states supplement, or match, with additional credits. As a result, if the taxpayer lives in a state that offers a state EITC, the total EITC (federal plus state) could be much larger; for example, New York residents receive an additional $30 \%$ of the federal credit. The slope of the EITC function is steeper in the phase-in range than in the phase-out range. That is, an additional dollar of earned income rewards households in the phase-in region more by giving them a credit, which can range from $\$ 0.07$ (for childless singles) to $\$ 0.45$ (for married couples with three or more children). In the phase-out range, an additional dollar of income results in a reduction in the credit, from $\$ 0.07$ (for childless singles) to $\$ 0.21$ (for married couples with two or more children).

Table 1. EITC Parameters, Tax Year 2012

\begin{tabular}{|c|c|c|c|c|c|c|}
\hline \multirow[b]{2}{*}{ Type of Return } & \multicolumn{4}{|c|}{ Dollars } & \multicolumn{2}{|c|}{ Percent } \\
\hline & $\begin{array}{l}\text { Maximum } \\
\text { credit }\end{array}$ & $\begin{array}{c}\text { Maximum } \\
\text { eligible } \\
\text { earnings }\end{array}$ & $\begin{array}{c}\text { Begin } \\
\text { phase-out }\end{array}$ & $\begin{array}{c}\text { Break even } \\
\text { point }\end{array}$ & Credit rate & $\begin{array}{l}\text { Phase-out } \\
\text { rate }\end{array}$ \\
\hline \multicolumn{7}{|l|}{ Single Filers } \\
\hline Childless & 475 & 6,210 & 7,770 & 13,980 & 7.65 & 7.65 \\
\hline One child & 3,169 & 9,320 & 17,090 & 36,920 & 34.00 & 15.98 \\
\hline Two children & 5,236 & 13,090 & 17,090 & 41,952 & 40.00 & 21.06 \\
\hline Three or more children & 5,891 & 13,090 & 17,090 & 45,060 & 45.00 & 21.06 \\
\hline \multicolumn{7}{|l|}{$\begin{array}{l}\text { Married Couples } \\
\text { Filing Jointly }\end{array}$} \\
\hline Childless & 475 & 6,210 & 12,980 & 19,190 & 7.65 & 7.65 \\
\hline One child & 3,169 & 9,320 & 22,300 & 42,130 & 34.00 & 15.98 \\
\hline Two children & 5,236 & 13,090 & 22,300 & 47,162 & 40.00 & 21.06 \\
\hline Three or more children & 5,891 & 13,090 & 22,300 & 50,270 & 45.00 & 21.06 \\
\hline
\end{tabular}

The range of eligible income is much larger as the number of dependent children rises. As of 2012, married households with three or more children earning less than $\$ 50,270$ qualify for the EITC, compared to $\$ 19,190$ for childless couples. The maximum EITC does not vary with marital status, but the income eligibility ranges are slightly larger for married couples. In 
addition, the range of eligible income is much larger in the phase-out range so that more households are in the phase-out range than in the phase-in range. In fact, married households are more likely to be in the phase-out range than singles, since they are more likely to have higher household income.

The EITC represents a negative income tax for households who qualify for it. Thus, for low income levels, marginal income tax rates are negative. Using data from TAXSIM version 9.0 from the NBER, ${ }^{10}$ I calculate the marginal income tax rates for all single and married households with no children, one child and two children (i.e., dependents exemptions) for tax year 2008. ${ }^{11}$ The marginal income tax rate is for adjusted gross income only and does not include FICA contributions (i.e., Social Security and Medicaid).

In Figure 6, I plot the marginal tax rates across income levels for single and married filing status earning up to $\$ 100,000$ and differentiate households based on the number of children they claim as dependants. As you can see in the first panel for married households with two or more children, for low levels of income, the marginal tax rate is $-40 \%$ for both single and married filers, which represents the phase-in rate for the EITC. As incomes reach $\$ 13,000$, the marginal rate is $0 \%$ (in the plateau region). For households with income above $\$ 13,000$, the marginal tax rate becomes positive and gets quite large quickly. For married households with incomes between approximately $\$ 19,000$ and $\$ 25,000$, the marginal tax rate jumps to $21 \%$, which represents the EITC phase-out rate. That is, at the margin, these households are experiencing a 21\% reduction in their EITC for any additional income they earn in this range. For married households with incomes between approximately $\$ 25,000$ and $\$ 40,000$, the marginal income tax rate increases to 31\%, which represents the EITC phase-out rate plus the lowest

\footnotetext{
${ }^{10} \mathrm{http} / / /$ www.nber.org/ taxsim/taxsim-calc9/index.html

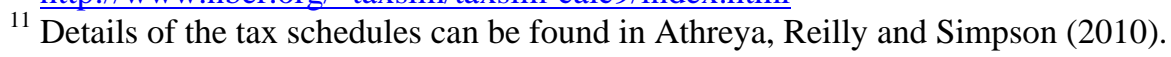


income tax bracket of $10 \%$. For married households with two children earning $\$ 41,000$, they face the phase-out rate and the next highest tax bracket of $15 \%$, making their marginal tax rate 36\%. Thus, the phasing out of the EITC leads to dramatic increases in the marginal income tax rates for these households. For married households above $\$ 41,000$, they no longer qualify for the EITC; hence, they face significant reduction in their marginal tax rates, at 15\% (in the second income tax bracket). As household income approaches $\$ 90,000$, the marginal tax rate increases to $25 \%$ for married filers. ${ }^{12,13}$ Single taxpayers with two children experience similar jumps in the marginal income tax rates, but for lower levels of income than married households.

The second panel in Figure 6 shows the marginal income tax schedule for married and single households with one child. The figure is similar for those with two or more children, however, the marginal rates are slightly lower across all income levels. In the last panel of Figure 6, the income tax schedule is quite different for those with no children compared to those with children. Recall that the EITC is much less generous for childless households. Thus, the negative marginal rates are quite low (in absolute value terms) for the poorest households. Also notice also that the increases in the marginal rates are not as extreme for childless singles; as a result, these households do not experience significant reductions in their marginal tax rates as they become ineligible for the EITC (for incomes above $\$ 15,800$ for married households). Beyond EITC eligibility, they face the same marginal income tax rates as households with children.

\footnotetext{
${ }^{12}$ Marginal tax rates in the U.S. increase up to $35 \%$ for household incomes up to $\$ 357,000$ (in 2008). However, I focus on income tax rates for low and middle-income households.

${ }^{13}$ If I were to include FICA contributions, the entire marginal tax curve would shift upward by 7.65 percentage points across all income levels.
} 
Figure 6. Marginal Tax Rates with the EITC, Tax Year 2008
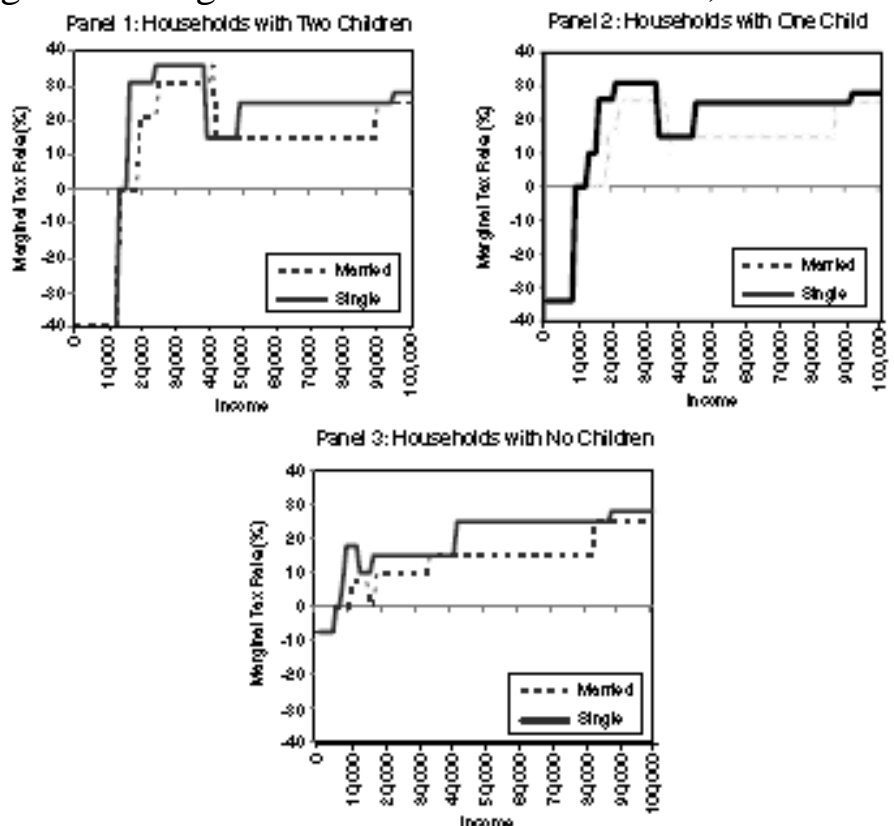

Source: Athreya, Reilly and Simpson (2010)

Our analysis of the marginal income tax schedule for EITC recipients uncovers a few interesting points. First, the poorest households with children (those earning below $\$ 12,000$ ) experience large negative income tax rates (in absolute value terms) due to the EITC. Second, single parent households that receive the EITC face some of the highest (positive) marginal income tax rates in the U.S. (Ellwood and Liebman, 2001); for example, a single mother with two children earning $\$ 35,000$ pays a marginal income tax rate of $36 \%$ (in 2008). These high marginal tax rates can be attributed to the phasing-out of the EITC and the progressive income tax schedule (Romich, 2006). Married households with children face slightly lower marginal tax rates than single households with children. Third, once households with children no longer qualify for the EITC, their marginal income tax rates drop significantly, and once they surpass EITC eligibility, marginal income tax rates no longer depend on the number of children in the household. 
Since the EITC affects marginal income tax rates, it has the potential to affect both the decision to work (i.e., the extensive margin) and the number of hours worked (the intensive margin). In a static labor-leisure model, the EITC increases the marginal value of working (i.e., the after-tax wage rate). Thus, in theory, the EITC will increase labor market participation. However, the effects of the EITC on hours worked are theoretically ambiguous.

I next describe the typical labor-leisure model but include the EITC, closely following Eissa and Hoynes (2011), Gruber (2010) and Athreya, Reilly and Simpson (2010). Consider a representative household within the traditional labor-leisure model, where the household unit decides how much to work. The household could constitute one or more workers, where the trade-off to working is household leisure. The budget constraint (without the EITC) is depicted by: $c=\tilde{w}^{*} n$ where $c$ represents consumption, $\tilde{w}$ represents after-tax wages, and $n$ represents labor hours. Households have $T$ units of time to devote to labor $(n)$ and leisure $(l) ; T=n+l$. The slope of the budget constraint, and hence the cost of pursuing an additional unit of leisure, is $\widetilde{w}$ units of consumption.

The EITC changes the after-tax wage rate $(\tilde{w})$ for different levels of leisure/labor. For low levels of labor, when the household receives a tax credit (i.e., a negative tax) for each additional unit of labor, the after-tax wage is $\widetilde{w}=w\left(1+t_{s}\right)$, where $t_{s}>0$ is the phase-in rate. For higher levels of labor in the plateau region, the after-tax wage is simply $w$ since the EITC is constant in this range; that is, $\widetilde{w}=w$ where households receive a transfer $T r$. During the phaseout region, the after-tax wage is $\widetilde{w}=w\left(1-t_{p}\right)$; the EITC falls for each additional unit of labor at the rate $t_{p}>0$. For very high levels of labor, the after-tax wage returns to $w$ once again. Thus, the budget constraint is as follows: $c=w\left(1+\tau_{p}\right) * n$ for $n \in\left(0, n_{1}\right) ; c=w^{*} n+\operatorname{Tr}$ for $n \in\left[n_{1}, n_{2}\right) ; c=w\left(1-t_{s}\right) * n$ for $n \in\left[n_{2}, n_{3}\right) ; c=w^{*} n$ for $n \in\left[n_{3}, T\right)$; where $\operatorname{Tr}$ is the 
maximum EITC and $n_{i}$ represents different quantities of labor. The EITC budget constraint, as plotted in Figure 7, is kinked at each quantity of labor $n_{i}$ in which $\tilde{w}$ changes.

Figure 7. Budget Constraint with and without the EITC

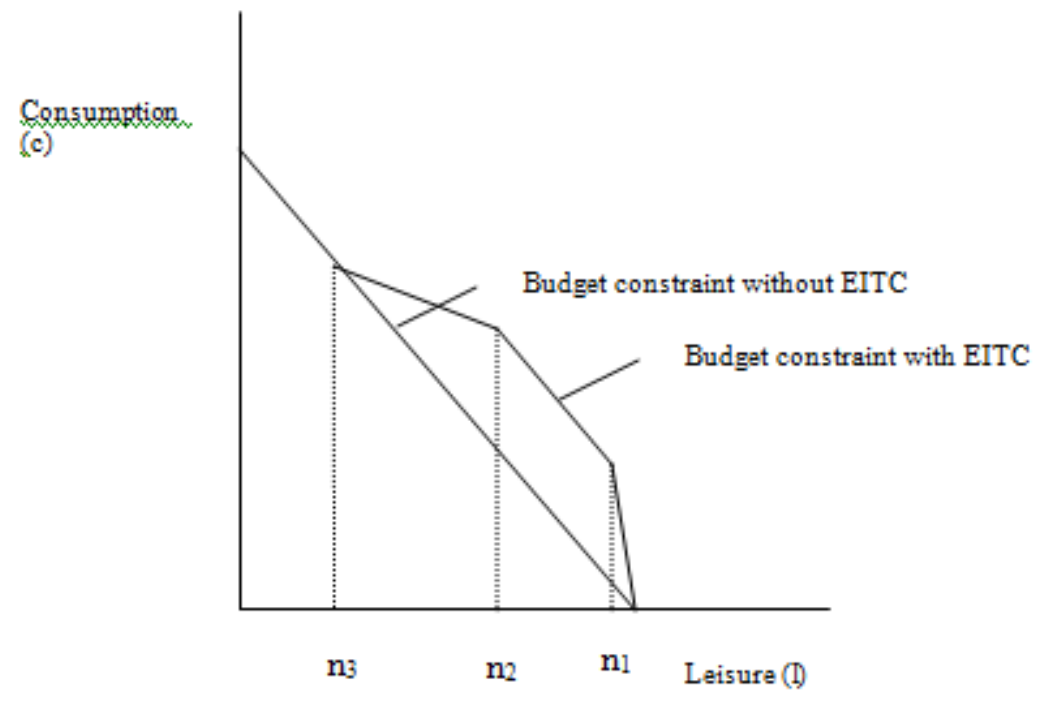

Source: Athreya, Reilly and Simpson (2010)

By comparing the budget constraint with and without the EITC in the various ranges of labor supply, one can determine the theoretical effects of the EITC on hours worked. First notice that for households who do not work $(l=T)$, the EITC is zero and has no effect on the household's budget constraint. However, for those households who choose to work very little (i.e., $n=\varepsilon$ where $\varepsilon \in\left(0, n_{1}\right)$ ), the slope of the budget line gets steeper. Here, there is a positive substitution effect and no income effect. Thus, the EITC may influence some households to enter the labor force, leading to a positive effect on the extensive margin.

However, the effects of the EITC on the intensive margin are more complicated. In the phase-in range, the slope of the budget constraint is higher with the EITC ( $\tilde{w}>w$ since $\left.t_{s}>0\right)$; thus, a negative income effect and a positive substitution effect are both at play, making the effects on hours worked ambiguous. Those in the plateau region receive the same amount of 
credit if they earn more income, and hence a pure income effect occurs in which higher income reduces the incentive to work. In the phase-out range, the slope of the budget constraint is flatter than without the EITC $\left(\tilde{w}<w\right.$ since $\left.t_{p}>0\right)$. Here, a negative substitution effect influences households to substitute leisure for hours worked. In addition, a negative income effect may reduce hours worked even more. Thus, households in the phase-out region unambiguously reduce hours worked. For those with income beyond the phase-out region $\left(n \in\left[n_{3}, T\right)\right)$, their return to an additional hour of work is $w$, so that some of them may choose to restrict labor hours to be eligible for the EITC, once again leading to a negative effect on the extensive margin.

Of course, the magnitude of these responses depends on the elasticity of labor supply. High elasticity leads to larger labor supply responses and labor supply elasticities vary across different types of people. For example, the uncompensated elasticity of labor supply is higher for women than for men and the elasticity on labor force participation is larger than the elasticity of hours (Evers, Mooij and Van Vuurren, 2008). Thus, the quantitative effects of the EITC on both the extensive and intensive margins of labor supply decisions depend critically on the elasticity of labor supply.

There is a large empirical literature that examines the effects of the EITC on labor supply, with most of the work focusing on single mothers. ${ }^{14}$ The evidence indicates that the EITC does in fact increase labor force participation, and especially for single mothers (Meyer, 2001), leading to positive effects on the extensive margin. However, the effects of the EITC on the intensive margin are less clear in the data, with most studies not finding a significant change in hours worked due to the EITC. Cancian and Levinson (2005) argue that there is essentially zero effect on hours, based on a natural experiment arising from the fact that one US state

\footnotetext{
${ }^{14}$ For a more detailed summary of this literature, refer to Holt (2006) and Hotz and Scholz (2003).
} 
(Wisconsin) altered the generosity of its matching of the Federal EITC. There is some evidence suggesting that single mothers may work more in response to the EITC since they are likely to be in the phase-in region where marginal income tax rates are negative (Eissa and Liebman, 1996). Married women, however, who typically fall in the phase-out range, may work fewer hours as a result of the EITC rates (Ellwood, 2000; Eissa and Hoynes, 2004). Overall, the EITC has small negative effects on both the extensive and intensive margins for married couples.

Studies have shown that the labor supply of low-income households is generally unresponsive to high marginal tax rates (Keane and Moffitt, 1998; Gruber and Saez, 2002); this compares to high-income workers who are quite responsive to tax rates. Perhaps low-income workers cannot adjust their work hours due to their job structure (Romich, 2006). Or perhaps these workers do not realize the high marginal tax rates due to the complexity of the income tax and benefits structure in the U.S. Recent theoretical work in a separate, but related context, suggests that a central force may be that these households are low-income and hence low-wealth. As a result, these households will often be close to a borrowing constraint. Consumption theory predicts that such households will work in a manner insensitive to current wages, as the value of lowering the likelihood of a binding borrowing limit (by working and reducing consumption) will be high (Pijoan-Mas, 2006).

In ongoing work, Athreya, Reilly and Simpson (2013) utilize this insight and embed households into a setting in which they face uninsurable risks and liquidity constraints, and find that indeed, the disincentives to labor supply arising from the EITC are not strong for single mothers. In fact, the EITC has important positive effects on the extensive margin of labor supply and no effect on the intensive margin. Their results stem from the fact that EITC-recipient 
households face tight borrowing constraints, so that their labor supply response to the EITC is small.

Given that the EITC targets families with children and that there are some marriage penalties associated with it (Ellwood, 2000), it is theoretically plausible that the EITC has important behavioral effects on marriage, cohabitation and fertility. Ellwood (2000) studies the marriage and cohabitation responses to the EITC, and finds negligible effects on marriage. He states: “Though the EITC sharply reduced marriage penalties and welfare reform has pushed many people off welfare, there is no dramatic increase in marriage or decrease in cohabitation among the lowest skill single mothers. But there is at least some possibility that marriage and cohabitation patterns have been changed slightly, especially among older women” (p.1100).

Dickert-Conlin and Houser (2002) study the marriage effects of the EITC expansions in the mid-1990s for married women and unmarried women. They find that married women with children are less likely to remain married as a result of the EITC, but the effects are economically insignificant. In addition, they find no relationship between the EITC and marriage for unmarried women.

The EITC could also affect fertility decisions since the tax credit increases in size with the number of children (recall that the maximum credit for a family with one child is $\$ 3,169$ and $\$ 5,891$ for a family with three or more children). It is important to differentiate between the first birth and other births; that is, the effects of the EITC differ in the extensive and intensive margins of fertility, just as they do for labor supply. Based on standard economic theory, the EITC should encourage a first birth for all eligible women based on unambiguous price and income effects (Baughman and Dickert-Conlin, 2009). Since the credit increases with the number of children, the EITC also provides a positive (price) effect incentive for a second child. 
However, the fertility and labor supply decisions can interact in important ways and depend on where households are in the EITC structure. Baughman and Dickert-Conlin (2009), in a comprehensive study on the EITC and fertility, state: "If we assume children are normal goods, mothers with income in the phase-in range of the EITC face an ambiguous incentive for additional children. However, mothers with income in the flat- and phase-out range face an unambiguously positive incentive to have a second (but not a third or higher order) birth” (p. 545). Today, given that the EITC is larger for families with three or more children (since 2009), there is a positive effect of having a third child. The empirical findings of Baughman and Dickert-Conlin (2009), however, suggest only small effects on fertility rates for single white women between 1990 and 1999 using state-level data. In fact, their empirical findings the fertility rates for single white women are inversely related to the EITC for the both extensive and intensive margins of fertility, but the coefficients are economically insignificant. They find weak, positive effects of the EITC for their non-white sample. However, Baughman and Dickert-Conlin (2009) find that other tax policies, namely child tax credits and child care credits, have positive effects on fertility.

The distribution of EITC payments happens through the income preparation process and as a result is lumpy. As such, the lumpiness of EITC payments can have important seasonal effects on consumption and the aggregate economy. In fact, EITC disbursements are largest in February, and over time come earlier in the calendar year (Edwards, 2004). Edwards (2004) uses macroeconomic data to measure and characterize the consumption effects of the EITC and estimates that approximately 70 percent of the credit is spent on average, and EITC recipients are more likely to be spenders than savers (a finding consistent with micro-level data; see Simpson, Hyde and Tiefenthaler, 2010). In fact, Edwards (2004) finds that consumption increases in both 
durable and nondurable goods at similar levels, but not in services. Barrow and McGranahan (2001) show that at least some EITC-recipient households are putting part of their EITC towards durables purchases. Thus, it seems as if the EITC is an effective fiscal stimulus device since a large share of the credit is going towards the purchases of goods and services.

4. Macroeconomic Effects of Welfare Reform and the U.S. Safety Net in the Great Recession Welfare reform, expansion of the EITC, and creation of the Child Tax Credit occurred simultaneously during the late 1990s. As a result, there were significant changes in the labor market, and in particular on female labor force participation. In this section, I will discuss some of the macroeconomic effects of the changing fiscal landscape since the 1990s. Welfare form also fundamentally changed the nature of the U.S. safety net, and this has recently caught the attention of policymakers in the wake of the Great Recession. Thus, I will present recent data on the usage of other components of the U.S. safety net and comment on their effectiveness.

First, the installation of lifetime limits with TANF beginning in 1996 fundamentally changed the labor supply response to these programs, and especially for single mothers. As a result of TANF and the expansions of the EITC, the labor force participation rates for single mothers began to increase starting in the early 1990s. As Figure 8 documents, single mothers displayed the largest increases in employment rates among all women in the period between 1992 and 2003. In fact, employment rates for all other types of women (single without children, and married women with and without children) do not noticeably change during this period. Grogger (2003) finds that welfare reform accounted for approximately 14 percent of the total rise in employment among single mothers between 1993 and 1999, while expansions of the EITC accounted for an even larger share of 34 percent. 
Figure 8. Annual Employment Rates for Women by Marital Status and Presence of Children, 1984-2003

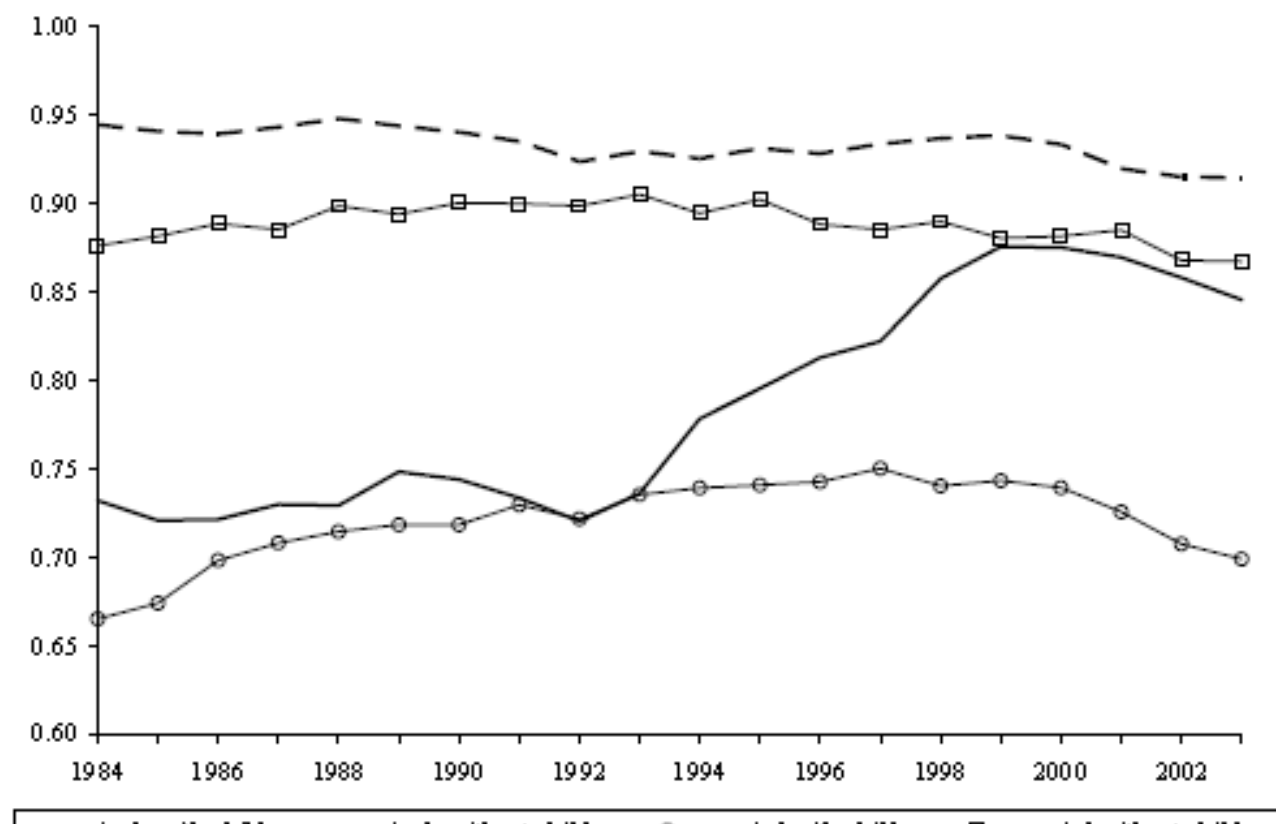

- single with children - - single without children - - - married wifh chiliren $\square$-married without children

Nates: Calculations baed an the 1985-2004 March CPS and include wamen ages $1944, \mathrm{nat}$ in schod and not dis abled. It also excludes wamen with positise eaming but sero hour and those with poitive hours and s ero earnings. Manried women include those with spouse present and sin gle women include divorced, widowed and never manried women. Figure shows the fraction of wamen whow odked at all in the calendar year.

Source: Eissa and Hoynes (2006)

Eissa, Kleven and Kreiner (2008) report that the largest gains in female employment rates occurred for women with two or more children, as evident in Figure 9. The labor force participation rates for women with one child increased, but the largest increases occurred for those with two or more children. This compares to very little changes in the labor force participation rates for women without children. In fact, the labor force participation rate for women with different numbers of children nearly converge by the year 2000 (Figure 9).

Overall, many of the gains in employment rates among women that occurred as a result of TANF and the EITC disappeared over time. According to a recent report by the Center on Budget and Policy Priorities (2012), “employment rates for TANF’s early years witnessed 
unprecedented declines in the number of families receiving cash assistance — and unprecedented increases in the share of single mothers working, especially those with less than a high school education. But since then, nearly all of the employment gains have disappeared, and TANF caseloads have responded only modestly to increased need during this deep and long downturn” (p. 1).

Figure 9. Labor force participation of unmarried females, 1989- 2000

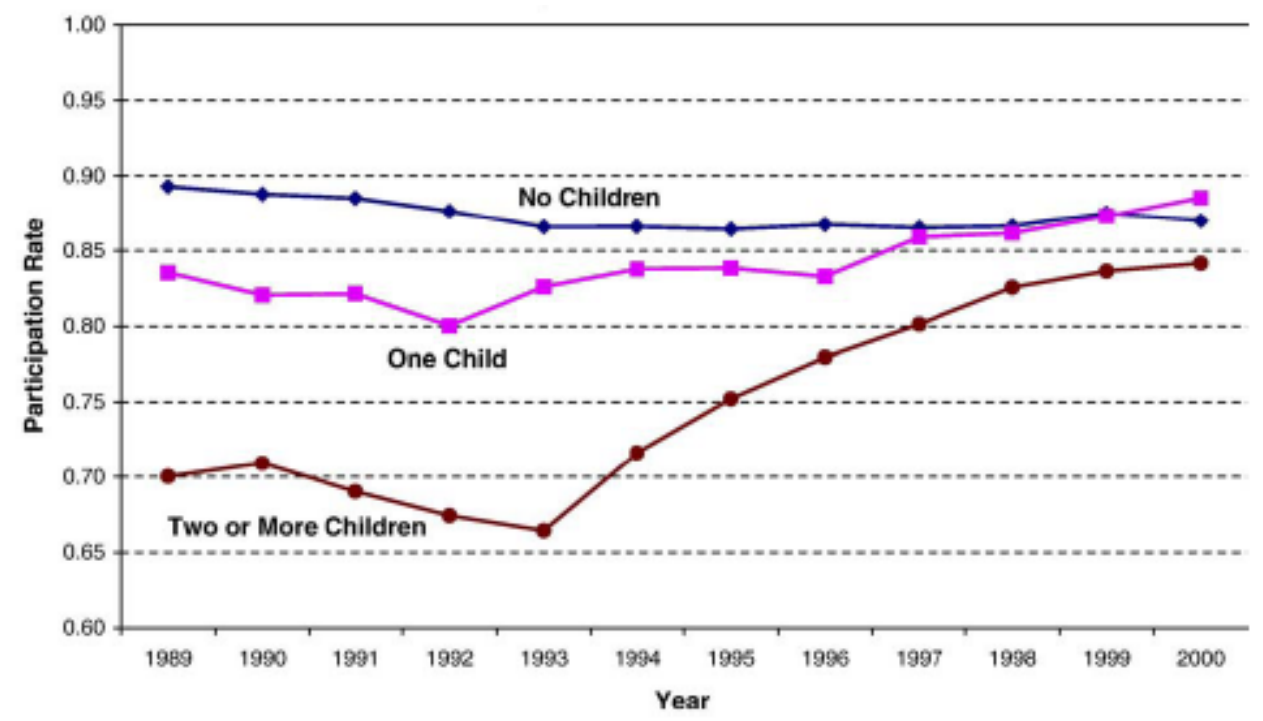

Source: Eissa, Kleven and Kreiner (2008), using CPS data

In 1992, the total number of welfare caseloads (on AFDC) nationally was approximately 5 million compared to approximately 2 million (on TANF) in 2010; thus, national caseloads declined by 60 percent between 1992 and 2010 (Center on Budget and Policy Priorities, 2012). Importantly, Loprest (2012) notes that variance in state TANF policy leads to differences in the reductions of state caseloads, with reductions ranging from 25 to 80 percent for different states. However, Ziliack et al. (2000) find that the decline in welfare caseloads in the early part of this period is mostly due to the strong economic growth of states rather than waivers to state AFDC policies. However, it is important to note that the reduction in TANF caseloads and total 
spending during the Great Recession is mostly like to the severe contracting in state budgets during this period. States just did not have the resources to allocate to the increasing pressures on TANF.

Over time and due at least in part to the welfare-to-work initiatives in the 1990s, take-up rates for traditional welfare (the percentage of eligible families receiving assistance) have fallen. According to Loprest (2012), take-up rates for TANF have declined since 1996, from 79 percent in 1996 to a low of 36 percent in 2007. This compares to take-up rates for the EITC of approximately 75 percent in recent years (Tax Policy Center, 2013). Thus, even for families that are eligible for welfare benefits, participation in traditional welfare has fallen significantly in the last two decades. Given the reduction in national welfare caseloads, total spending on TANF has remained relatively flat (in real terms) since the mid-1990s, as displayed in Figure 1. Recall that this period experienced significant increases in total Federal spending on the EITC and CTC.

Because fewer families receive TANF and benefits have decreased in real terms, "TANF plays a much more limited role in helping families escape poverty or deep poverty (i.e., income below half the poverty line) today than AFDC did” (Center on Budget and Policy Priorities, 2012, p. 1). Over the years, TANF has become less effective in helping low-income families in crisis. In fact, this was clearly demonstrated during the recession of 2007-2008, as welfare caseloads did not increase much at all, from 1.91 families in 2007 to 1.94 families in 2010 (Loprest, 2012).

However, other components of the U.S. safety net have been playing a more important role, especially since the Great Recession. In particular, the creation of the Making Work Pay tax credit, which was part of the 2008 Federal stimulus plan, provided a refundable tax credit equal to 6.2 percent of earned income up to $\$ 400$ for working individuals and up to $\$ 800$ for 
married taxpayers filing joint returns. Most earners benefited from larger paychecks in 2009 and 2010 due to reductions in federal income tax withholding. The credit phased out at a rate of 2 percent of income over $\$ 150,000$ for married couples filing joint tax returns and $\$ 75,000$ for others. ${ }^{15}$ Couples with income above $\$ 190,000$ and single-headed households with income above $\$ 95,000$ were not eligible to receive the credit. The Making Work Pay credit cost the Federal government close to $\$ 60$ billion in 2010, of which approximately $\$ 13$ billion were outlays and the rest stems from a reduction in tax revenues (CBO, 2013). Thus, the credit was similar in scope as the CTC (in 2010), although a larger share came from a reduction in tax revenues (CBO, 2013). However, the Making Work Pay credit was temporary and expired in December 2010, whereas the CTC continues to exist today.

Importantly, given that most tax credits are allocated by the Federal government during the income tax preparation process (with the exception of the Making Work Pay credit which was mostly allocated through paychecks), states are not directly involved with their distribution (except for states who offer state EITC’s). In addition, tax credits create important seasonal fluctuations with the majority of the disbursements occurring early in the tax season (namely, February). Moreover, tax credits are probably less effective in encouraging certain types of behaviors since recipient households must wait a long time to receive the subsidy (CBO, 2013).

Other components of the U.S. safety net are also allocated by the Federal level of government, and hence are countercyclical in nature. For example, participation and dollars spent in SNAP have increased significantly in recent years. Federal expenditures for SNAP were \$74 billion in 2012, and participation in the program was the highest it had ever been (USDA, 2013). In an average month that year, about one in seven U.S. residents received SNAP benefits. On average, 46 million people received SNAP benefits each month in fiscal year 2012, which

\footnotetext{
${ }^{15}$ http://www.taxpolicycenter.org/taxtopics/conference_makingworkpay.cfm
} 
represents a 77 percent increase since 2007 when 26 million people received SNAP. Total SNAP benefits (not including administrative costs) more than doubled during that period, from about \$30 billion to \$74 billion.

Participation in SNAP in the last several years has increased for several reasons: the recession increased the number of eligible households and more households that were eligible participated in SNAP. According to the CBO (2012a), the number of households eligible for the program increased by an estimated 20 percent from 2007 to 2009. Both the weak economy and changes in the administration of SNAP (which made it easier for households to apply) increased the number of eligible households receiving SNAP. In addition, take-up rates increased and are now at approximately at 70 percent (Hanson and Oliveira, 2012).

Figure 10, SNAP Participation and Total Spending, 1990-2012

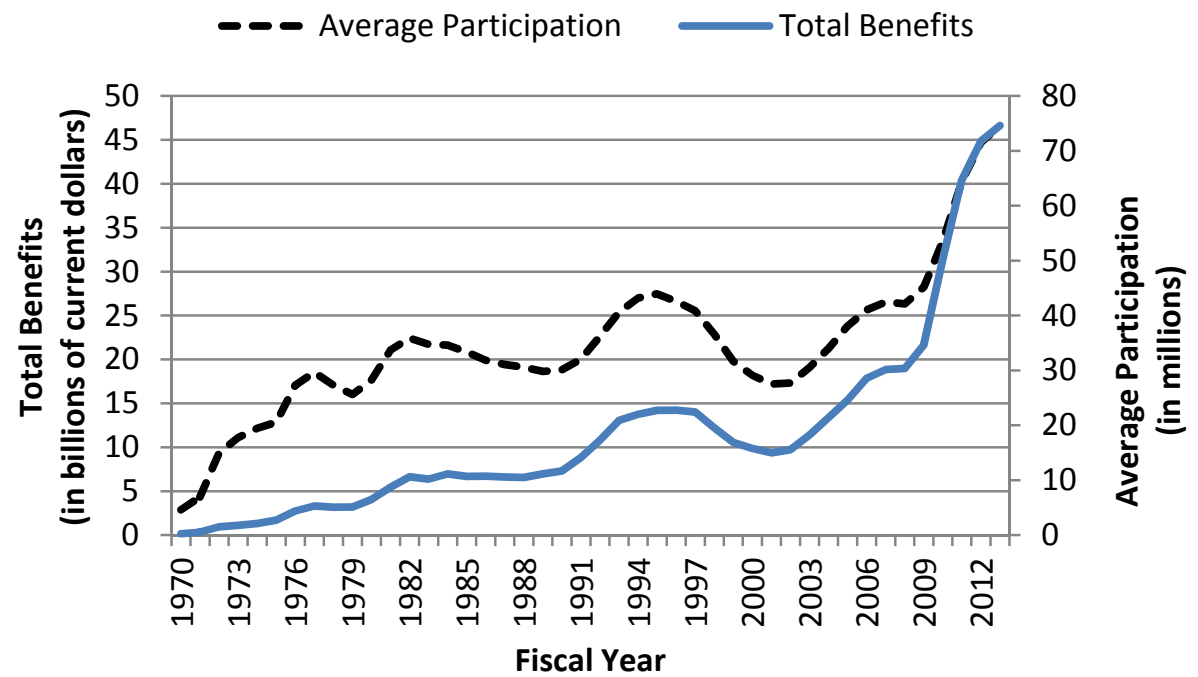

Source: Author's calculations using data from USDA (2013)

The Great Recession caused a tremendous amount of unemployment: the unemployment rate jumped from 4.6 percent in 2007 to 10 percent in 2010 and is still at 7.9 percent at the 
beginning of $2013 .{ }^{16}$ Even more striking was the average length of an unemployment spell, peaking at 40 weeks at the end of 2011, up from 17 weeks in $2007 .{ }^{17}$ Unemployment insurance is one of the truest forms of an "automatic stabilizer" in the U.S. economy, in which benefits are directly linked to the state of the macroeconomy. Typically, individuals can receive 26 months of unemployment benefits. As a result of the slow recovery in the labor market, the Federal government extended the duration that individuals could collect unemployment benefits in the Great Recession. The maximum number of weeks that individuals could collect unemployment insurance was 99 weeks, based on a tier system (i.e., through the Emergency Unemployment Compensation Tiers 1-4 and Extended Benefits programs).

Total expenditures on unemployment insurance benefits peaked in 2010 totaling nearly $\$ 160$ billion, as displayed in Figure 11 (CBO, 2012b). This compares to $\$ 119$ billion spent in 2011 and $\$ 120$ billion in 2009, a substantial increase over the $\$ 33$ billion paid out in fiscal year 2007 (when the unemployment rate was 4.6 percent). The CBO (2012b) estimates that unemployment insurance (UI) benefits totaled \$94 billion in fiscal year 2012 (when the unemployment rate was 8.3 percent, on average). As expenditures peaked in 2010, the number of individuals receiving UI peaked at just over 14 million (Figure 12).

\footnotetext{
${ }^{16}$ Federal Reserve Economic Data

${ }^{17}$ Ibid
} 
Figure 11. Spending on Unemployment Benefits, 2000-2012 (Billions of dollars)

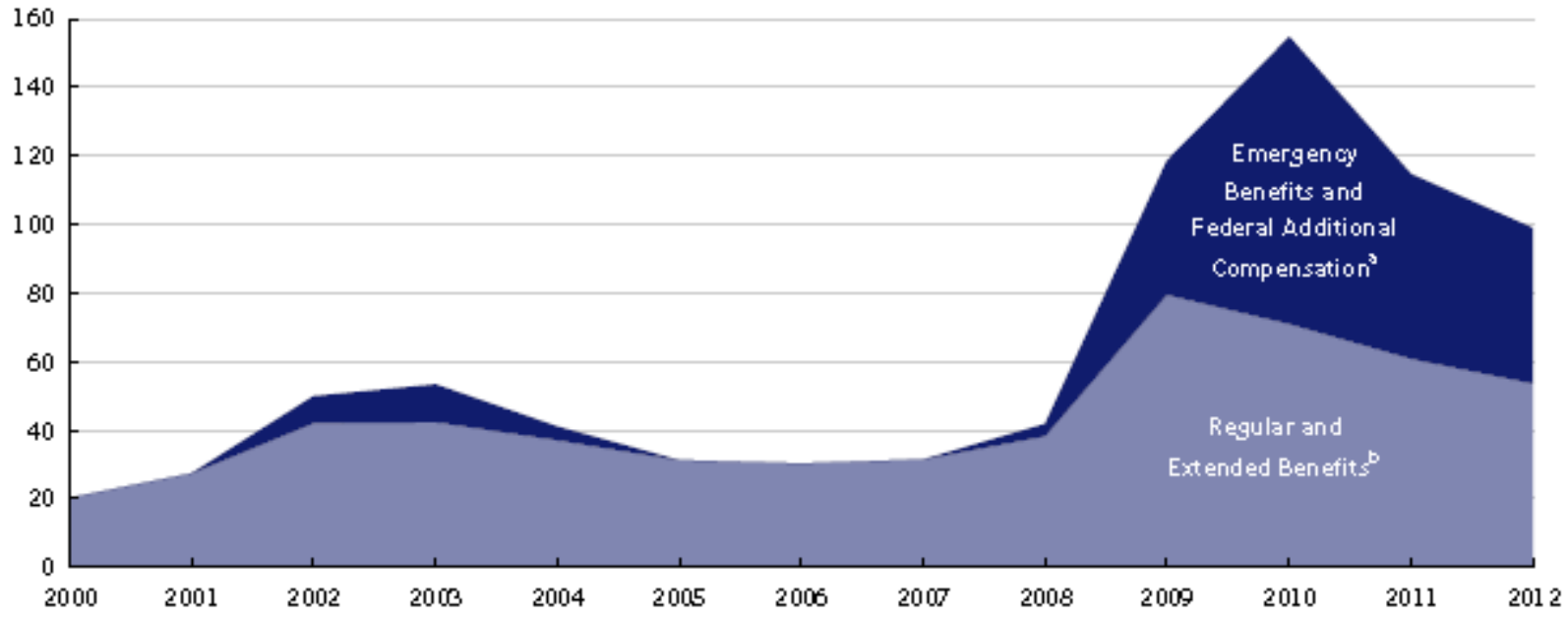

Sourde: Congressional Budget Office tased on data from the Department of Labor, Employ ment and Training uddminist ration.

a. Emegency benefits may be temporally authorized during periods of high unemp loy ment, as they were from March 2002 through March 2004 and from July 2008 through Dexmber 2012 . in weekly supplement of $\$ 25$, temed federal additional oompensation, was avalable to people reoiving unemployment benefits between February 2009 and June 2010.

b. Regular benefits are provided soonding to state aws under broad federal parameters. Typically, reguar benefits are avaikb be for up to 26 weeks. Extended benefits may provide an additional 13 or 20 weeks of benefits, depending on a states laws and unemp by ment rate.

Source: CBO (2012b)

Figure 12. Number of Individuals Receiving Unemployment Benefits, 2000-2012

(Millions)

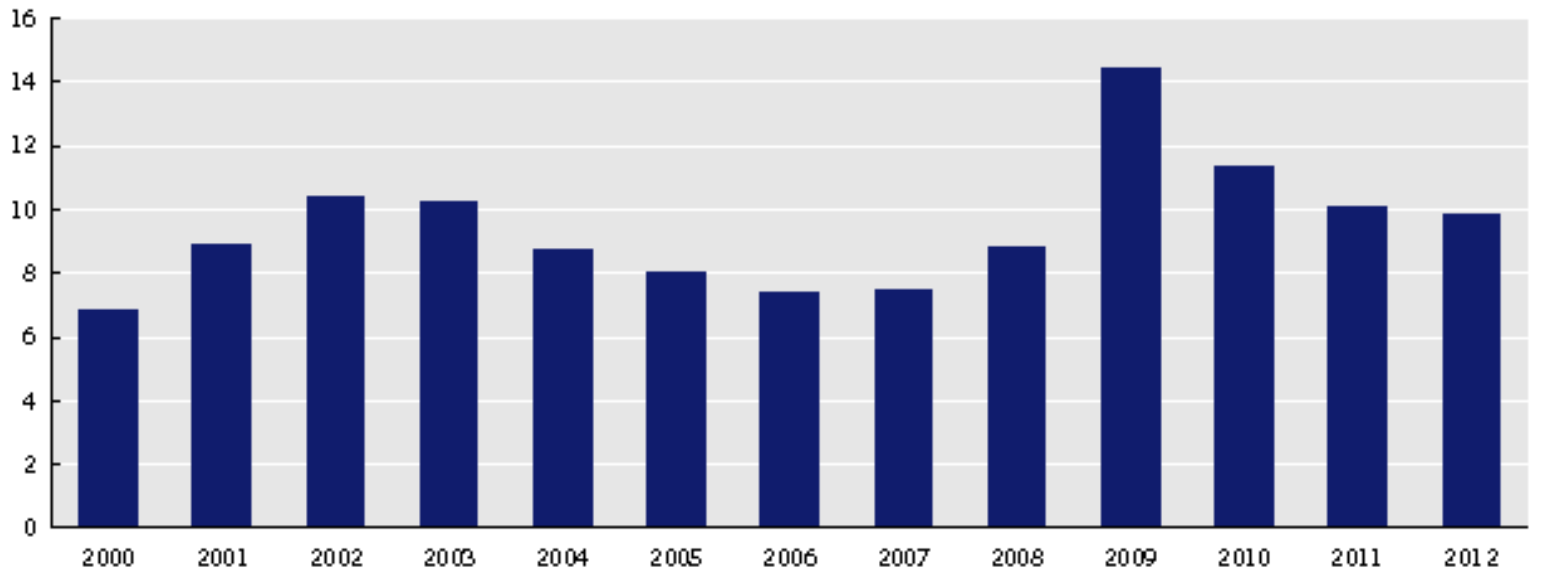

Source: CBO (2012b)

How the EITC responds in a recession is less clear. With higher unemployment, it is possible that some households lose their EITC eligibility (i.e., those who go from having earned 
income to not having earned income). Other households, especially two-earner households where one job is lost or hours are reduced, may become eligible for the EITC in a weak labor market. Thus, the overall number of recipient households may increase or decrease, depending on which effect is larger. In terms of dollars allocated, the effects are also ambiguous. Annual incomes fall in a recession, so that EITC payments could go up or down, depending on the number of households in the phase in and phase out ranges. Given that more households are in the phase out range, it is likely that overall payments would rise (since in the phase-out range, the EITC rises as income falls). Thus, the EITC serves as an effective component of the safety net, in which participation and dollars spent increase during a recession. However, the effects are not going to be as large as increases in SNAP and unemployment benefits, as documented above. SNAP and UI, at least in the Great Recession of 2007-08, experienced dramatic increases in both recipients and dollars spent. Temporary tax credits, such as the Making Work Pay credit, also played an important role in alleviating economic pressures for working households. However, traditional welfare played a much smaller role, indicating that non-working households experiencing a tremendous amount of economic hardship are not being helped much by the U.S. safety net as it exists today.

\section{Conclusion}

The evolution of U.S. tax and transfer programs has been significant in the last two decades. Income tax rates have fallen, while tax credits have been created and expanded upon. At the same time, the U.S welfare system was overhauled in the mid-1990s. In this chapter, I summarize the characteristics of the U.S. income tax and transfer system as it currently exists and analyze its effects on U.S. families, with an emphasis on the Child Tax Credit and the 
Earned Income Credit. I also discuss the effectiveness of the U.S. safety net during the Great Recession, and show how temporary tax credits, unemployment insurance and food stamps have played crucial roles in helping U.S. families when they need it most. This compares to TANF, the current welfare system in the U.S., in which participation and spending levels have not changed much from their pre-recession figures.

The topic of analyzing how fiscal policies affect families is very important, and one that has garnered some attention in the Economics literature. However, work remains to be done. For example, many of the tax credits that exist today in the U.S. are relatively new (with the exception of the EITC), and hence have not been scrupulously analyzed. For example, very little is known about the fertility and labor supply decisions of the Child Tax Credit, which has existed in the U.S. since 1997. Additionally, the impacts of the CTC on consumption patterns, both at the household and macroeconomic level, are currently not well-understood.

Given that participation and spending on TANF did not dramatically increase in the Great Recession, academic discussions should inform policymakers about how TANF can be changed to still be politically palatable without compromising its role as an automatic stabilizer in the midst of recessions. Importantly, changes must be made to TANF with an understanding of how changes would affect the labor market, fertility and consumption decisions for U.S. households living in or near poverty.

As I have documented above, tax credits now represent a significant portion of U.S. fiscal policies targeting families, but more needs to be understand how the seasonality of the distributions (which occurs during the income tax process in the Spring) affects households' consumption and savings patterns. These distributions have important macroeconomic effects, both in terms of timing and in terms of the types of goods and services that are bought with tax 
returns, which are currently not well-documented. In addition, annual fluctuations in the receipt of tax credits in different macroeconomic environments need to be addressed, especially in the wake of the Great Recession. How has the EITC, for example, responded since the Great Recession, and have families adjusted their economic decisions accordingly? Many tax credits are allocated to both low- and middle-income households, with only the very highest income households being phased out. A deeper understanding of how these credits differentially impact low- and middle-income households is needed.

Finally, unemployment insurance and food stamps have both been a central component of the U.S. safety net during and since the Great Recession. Food stamp participation has dramatically increased, and many of the recipient households will likely continue to use food stamps well after the recession ends. This will have long-lasting implications on food stamp usage, which needs to be evaluated. Similarly, the flexibility of the U.S. unemployment insurance program no doubt dampened the adverse effects of the recession. However, the longterm unemployment that still remains in the U.S. labor market will have negative effects for the foreseeable future. Work will have to be done to assess the long-run consequences of long-term employment, and new programs may have to be developed to cater to families affected by long unemployment spells.

The Great Recession highlighted the parts of the U.S. safety net that need to be tweaked to ensure that the system of tax credits and transfer programs in the U.S. is sufficient in meeting needs. Ultimately, policies are set by politicians, but hopefully academic findings on how taxes and transfers affect U.S. families will inform these debates. 


\section{References}

Alm, James and Leslie A. Whittington. (1995). "Income Taxes and the Marriage Decision." Applied Economics. 27:1, pp. 25-31.

Alm, James and Leslie A. Whittington. (1997). "'Til Death or Taxes Do Us Part: The Effect of Income Taxation on Divorce." The Journal of Human Resources 3, 2:2, pp. 388-412.

Alm, James and Leslie A. Whittington. (1999). "For Love or Money? The Impact of Income Taxes on Marriage." Economica, 6:261, pp. 1-24.

Athreya, K., D. Reilly and N. Simpson. (2010). "The Earned Income Tax Credit: Life-Cycle Income, Marginal Tax Rates, Wealth and Credit Constraints.” Economic Quarterly 96(3): 229258.

Athreya, K., D. Reilly and N. Simpson. (2013). “The Earned Income Tax Credit for Single Mothers: Insurance Without Disincentives?” Colgate University Working Paper.

Austin, Andrew D. \& Mindy Levit. (2010). "Mandatory Spending Since 1962.” Congressional Research Service 7-5700, September 15, 2010. https://opencrs.com/document/RL33074/

Austin, Andrew D. \& Mindy Levit. (2012). "Mandatory Spending Since 1962.” Congressional Research Service 7-5700, March 23, 2012. www.fas.org/sgp/crs/misc/RL33074.pdf

Barrow, L., \& McGranahan, L. (2001). The effects of the earned income credit on the seasonality of household expenditures. National Tax Journal, 53(4), 1211-1243.

Baughman, R., \& Dickert-Conlin, S. (2009). The earned income tax credit and fertility. Journal of Population Economics, 22(3), 537-563.

Becker, Gary S. (1991). A Treatise on the Family. Cambridge, MA: Harvard University Press.

Blow, L., Walker, I., \& Zhu, Y. (2012). Who Benefits from Child Benefit? Economic Inquiry, 50(1), 153-170.

Blundell, R. (2001). "Evaluating Labour Supply Responses to In-work Benefit Reforms for Low Income Workers.” in Marco Buti, Paolo Sestito and Hans Wijkander (eds.), Taxation, Welfare and the Crisis of Unemployment in Europe, Edward Elgar, 157-187.

Bureau of Labor Statistics, (2010). U.S. Department of Labor, The Editor's Desk, Labor force participation rates among mothers. http://www.bls.gov/opub/ted/2010/ted_20100507.htm

Burman, L. E. and L. Wheaton (2005). Who gets the child tax credit? Tax Notes, October 17, Urban Institute. http://www.urban.org/url.cfm?ID=411232 
Cancian, Maria and Levinson, Arik. (2005). "Labor Supply Effects of the Earned Income Tax Credit: Evidence from Wisconsin Supplemental Benefit for Families with Three Children," National Bureau of Economic Research, Inc, NBER Working Papers: 11454.

Center on Budget and Policy Priorities, (2012). “Chart Book: TANF at 16.” http://www.cbpp.org/cms/index.cfm?fa=view\&id=3566

Congressional Budget Office, (2012a). “The Supplemental Nutrition Assistance Program.” April. http://www.cbo.gov/sites/default/files/cbofiles/attachments/04-19-SNAP.pdf

Congressional Budget Office, (2012b). "Unemployment Insurance in the Wake of the Recent Recession,” Congressional Budget Office. November.

Dickert-Conlin S. \& Houser S. (2002). EITC and marriage. National Tax Journal 55(1):25-40.

Edwards R. (2004). Macroeconomic implications of the earned income tax credit. National Tax Journal 57(1):45-65.

Eissa, N., \& Hoynes, H. W. (2004). Taxes and the labor market participation of married couples: the earned income tax credit. Journal of Public Economics, 88(9), 1931-1958.

Eissa, N., \& Hoynes, H. W. (2006). Behavioral responses to taxes: Lessons from the EITC and labor supply. In Tax Policy and the Economy, Volume 20 (pp. 73-110). The MIT Press.

Eissa, N., \& Hoynes, H. W. (2011). "Redistribution and Tax Expenditures: The Earned Income Tax Credit.” National Tax Journal, 64(2), 689-729.

Eissa, N. and J. Liebman. (1996). "Labor Supply Response to the Earned Income Tax Credit.” Quarterly Journal of Economics 61, 605-37.

Eissa, N., Kleven, H. J., \& Kreiner, C. T. (2008). Evaluation of four tax reforms in the United States: Labor supply and welfare effects for single mothers. Journal of Public Economics, 92(3), 795-816.

Ellwood, D. T. (2000). The impact of the earned income tax credit and social policy reforms on work, marriage, and living arrangements. National Tax Journal, 53(4; PART 2), 1063-1106.

Ellwood, David T., and Jeffrey B. Liebman. (2001). “The Middle Class Parent Penalty: Child Benefits in the U.S. Tax Code.” NBER Working Paper No. 8031. Cambridge, MA: National Bureau of Economic Research.

Evers, Michiel, Ruud De Mooij and Daniel Van Vuuren. (2008). “The Wage Elasticity of Labour Supply: A Synthesis of Empirical Estimates.” De Economist, Volume 156, Number 1, 25-43. 
Grogger, J. (2003). The effects of time limits, the EITC, and other policy changes on welfare use, work, and income among female-headed families. Review of Economics and Statistics, 85(2), 394-408.

Gruber, Jonathan. (2010). Public Finance and Public Policy, 3rd Edition. New York: Worth Publishers.

Gruber, Jon, and Emmanuel Saez. (2002). “The Elasticity of Taxable Income: Evidence and Implications.” Journal of Public Economics 84 (1): 1-32.

Hanson, K., \& Oliveira, V. (2012). How Economic Conditions Affect Participation in USDA Nutrition Assistance Programs. USDA, Economic Research Service, Economic Information Bulletin Number 100. September. http://www.ers.usda.gov/media/914042/eib100.pdf

Holt, Steve. (2006). “The Earned Income Tax Credit at Age 30: What We Know.” Metropolitan Policy Program, The Brookings Institution.

http://www.brookings.edu/reports/2006/02childrenfamilies_holt.aspx. Cited 16 March 2009

Hotz, V. Joseph, and John Karl Scholz. (2003). “The Earned Income Tax Credit.” In R. Moffitt, ed., Means-Tested Transfer Programs in the United States. Chicago: The University of Chicago Press and NBER.

Johnson, D. S., Parker, J. A., \& Souleles, N. S. (2009). “The Response of Consumer Spending to Rebates During an Expansion: Evidence from the 2003 Child Tax Credit.” Manuscript, Northwestern University.

Keane, Michael, and Robert Moffitt. (1998). “A Structural Model of Multiple Welfare Program Participation and Labor Supply.” International Economic Review 39 (3): 553-89.

Loprest, P. J. (2012). How Has the TANF Caseload Changed Over Time? http://www.urban.org/url.cfm?id=412565\&RSSFeed=UI_IncomeandBenefitsPolicyCenter.xml

Meyer, Bruce D. (2001). “Taxes, Welfare, and Work by Single Mothers.” NBER Reporter Online. Cambridge, MA: National Bureau of Economic Research, www.nber.org/reporter/fall01/meyer.html.

Meyer, B. and D. Rosenbaum (2001). "Welfare, the Earned Income Tax Credit, and the Labor Supply of Single Mothers.” Quarterly Journal of Economics 66, 1063-1114.

Michel, N., \& Ahmad, N. (2012). Consumer response to child tax credit. Empirical Economics, 43 (3), 1199-1214.

Pijoan-Mas, J., (2006). Precautionary Savings or Working Longer Hours? Review of Economic Dynamics 9, 326-352. 
Robins, P. K. (1985). "A Comparison of the Labor Supply Findings from the Four Negative Income Tax Experiments.” Journal of Human Resources 20, 567-82.

Romich, Jennifer L. (2006). "Difficult Calculations: Low-Income Workers and Marginal Tax Rates.” Social Service Review 80(1), 27-66.

Sherman, A. (2009). Recovery Agreement Temporarily Expands Child Tax Credit for Large Numbers of Children in Every State. Washington, DC: Center on Budget and Policy Priorities. http://www. cbpp. org/cms/index.cfm.

Simpson, N., Hyde, J. and J. Tiefenthaler. (2010). "The Impact of the Earned Income Tax Credit on Economic Well-being: A Comparison across Household Types," Population Research and Policy Review 29:843-864.

Tax Policy Center. (2009). "The American Recovery and Reinvestment Tax Act of 2009": Expansion of the Earned Income Tax Credit, Conference Report, Distribution of Federal Tax Change by Cash Income Percentile.” T09-0106: Feb.

Tax Policy Center. (2013). The Tax Policy Briefing Book: A Citizens’ Guide for the 2012 Election, and Beyond. Chapter 4: "Taxation and the Family: What is the Earned Income Tax Credit?” http://www.taxpolicycenter.org/briefing-book/key-elements/family/eitc.cfm

USDA. (2013). Supplemental Nutrition Assistance Program Participation and Costs, February 8, 2013. http://www.fns.usda.gov/pd/SNAPsummary.htm

Whittington, L.A., J. Aim, and E. H. Peters. (1990). "Fertility and the Personal Exemption: Implicit Pronatalist Policy in the United States." American Economic Review, 80(3):545-56.

Zhang, J., Quan, J., \& Van Meerbergen, P. (1994). The effect of tax-transfer policies on fertility in Canada, 1921-88. Journal of Human Resources, 181-201.

Ziliak, J. P., Figlio, D. N., Davis, E. E., \& Connolly, L. S. (2000). Accounting for the decline in AFDC caseloads: Welfare reform or the economy? Journal of Human Resources, 570-586. 